REFERENCES

Allerdice, P., Miller, O. J., Miller, D. A., Breg, W'. R., Gendel, E., and Zelson, C. (1971). Familial translocation involving chromosomes 6,14 , and 20 identified by quinacrine fluorescence. Humangenetik, 13, 205-209.

Breg, W. R. (1972). Quinacrine fluorescence for identifying metaphase chromosomes, with special reference to photomicrography. Stain Technology, 47, 87-93.

Breg, W. R., Miller, O. J., Miller, D. A., and Allerdice, P. W. (1972). Identifications of reciprocal translocation chromosomes by quinacrine fluorescence. American fournal of Diseases of Children, 123, 561-564.

Brogger, A. (1967). Translocations in Human Chromosomes, p. 110. Universitets Forlaget, Oslo.

Caspersson, T., Lomakka, G., and Zech, L. (1971). The 24 fluorescence patterns of the human metaphase chromosomes-distinguishing characters and variability. Hereditas, Genetiskt Arkiv, 67, 89102.

Chicago Conference: Standardization in Human Cytogenetics (1966). Birth Defects: Original Article Series, II, 2. The National Foundation-March of Dimes, New York.

Ford, C. E. and Clegg, H. (1969). Reciprocal translocations. British Medical Bulletin, 25, 110-114.

Giannelli, F. (1965). Autoradiographic identification of the D (1315) chromosome responsible for $D_{1}$ trisomic Patau's syndrome. Nature, 208, 669-672.

Hauschteck, E., Mürset, G., Prader, A., and Bühler, E. (1966). Siblings with different types of chromosomal aberrations due to $\mathrm{D} / \mathrm{E}$ translocation of the mother. Cytogenetics, 5, 281-293.

Jacobsen, P., Dupont, A., and Mikkelsen, M. (1963). Translocation in the 13-15 group as a cause of partial trisomy and spontaneous abortion in the same family. Lancet, 2, 584-585.

Miller, D. A., Allerdice, P. W., Miller, O. J., and Breg, W. R. (1971). Quinacrine fluorescence patterns of human D group chromosomes. Nature, 232, 24-27.

Miller, J. R., Dill, F. J., Corey, M. J., and Rigg, J. M. (1970). A rare translocation $(47, \mathrm{XY}, \mathrm{t}(2 \mathrm{p}-; 21 \mathrm{q}+), 21+)$ associated with Down's syndrome. Fournal of Medical Genetics, 7, 389-393.

Murken, J. D., Bauchinger, M., Palitzsch, D., Pfeifer, H., Suschke, J., and Haendle, H. (1970). Trisomie $\mathrm{D}_{2}$ bei einem $2 \frac{1}{2}$ jährigen Mädchen (47,XX,14 + ). Humangenetik, 10, 254-268.

Patau, K., Smith, D., Therman, E., Inhorn, S., and Wagner, H. P. (1960). Multiple congenital anomaly caused by an extra autosome. Lancet, 1, 790-793.

Taylor, A. (1968). Autosomal trisomy syndromes: a detailed study of 27 cases of Edwards' syndrome and 27 cases of Patau's syndrome. Fournal of Medical Genetics, 5, 227-252.

Taylor, M. B., Juberg, R. C., Jones, B., and Johnson, W. A. (1970). Chromosomal variability in the $\mathrm{D}_{1}$ trisomy syndrome. American Fournal of Diseases of Children, 120, 374-381.

\section{Normal Male Development with Y Chromosome Long Arm Deletion $(\mathrm{Yq}-)^{*}$}

Many observers have reported the variability in $\mathrm{Y}$ chromosome length and the apparent lack of any phenotypic effect attributable to a very long $\mathrm{Y}$.

Received 20 March 1972.

* This work was partially funded through an agreement with the Wisconsin Division of Health by the Children's Bureau, Department of Health, Education, and Welfare. This report was presented at the Tenth Annual Somatic Cell Genetics Conference in Aspen, Colorado, 18-20 January 1972.
Short $\mathrm{Y}$ chromosomes have been found in normal fertile males (Borgaonkar et al, 1969) as well as in families with diminished fertility (Muldal and Ockey, 1962). Large deletions of the $Y$ resulting in a fragment-like chromosome have been described in an intersex raised as a female (Lo and Kobernick, 1965), in a Turner's syndrome patient where it occurred with 45,X mosaicism (Ferguson-Smith et al, 1969), and in a severely retarded male baby (Nakagome et al, 1965). The case presented here is apparently the first in which an extreme deletion of the $\mathrm{Y}$ chromosome was found to be associated with fertility as well as normal male development.

\section{Case Report}

Chromosome studies were done on a 36-year-old mentally-retarded male (IQ 51), with several minor physical anomalies. $\mathrm{He}$ is $179 \mathrm{~cm}$ tall, with a normal male habitus, including heavy beard and normal external genitalia. During childhood, he had surgery for bilateral inguinal hernia and undescended testicles, but his testicles are now of normal adult size. He usually speaks with a peculiar high-pitched voice, but is capable of using deep voice tones on occasion. His chest shows pseudo-gynaecomastia, no true breast tissue being present.

The shape of the head is remarkably round, with a bilateral frontal-temporal depression and a low anterior hairline. The eyes appear deeply set, and he wears glasses for severe myopia. Brushfield spots are noted in the iris periphery. There is anteversion of both auricles, and the chin is prominent. Acne extends from his shoulders to the upper portions of his chest and back. In addition, he has numerous small, bright-red cavernous haemangiomas on the neck, arms, and scalp. Examination of the extremities shows hypoplasia of the 5th metacarpals, resulting in short-appearing 5th fingers. The big toes are short and slightly clubbed, and all of the finger and toenails are strikingly short in length.

The patient, the youngest of 4 children, was born when his mother was 32 years old. His sisters, now aged 44 and 42 , have had 2 and 3 children respectively, while his 43-year-old brother has 4 children. All of his sibs and their children are normal.

\section{Cytogenetic Studies}

Chromosome studies from a peripheral blood culture showed a karyotype of 46 chromosomes, all of which appear normal with the exception of what is presumed to be the $Y$ (Fig. 1). This is a small metacentric chromosome, less than half the size of the other $G$ chromosomes. When stained with quinacrine, no brightly fluorescent region attributable to the $Y$ chromosome was seen (Figs. 2 and 3 ). A buccal smear stained with quinacrine showed no fluorescing $\mathrm{Y}$ bodies. 


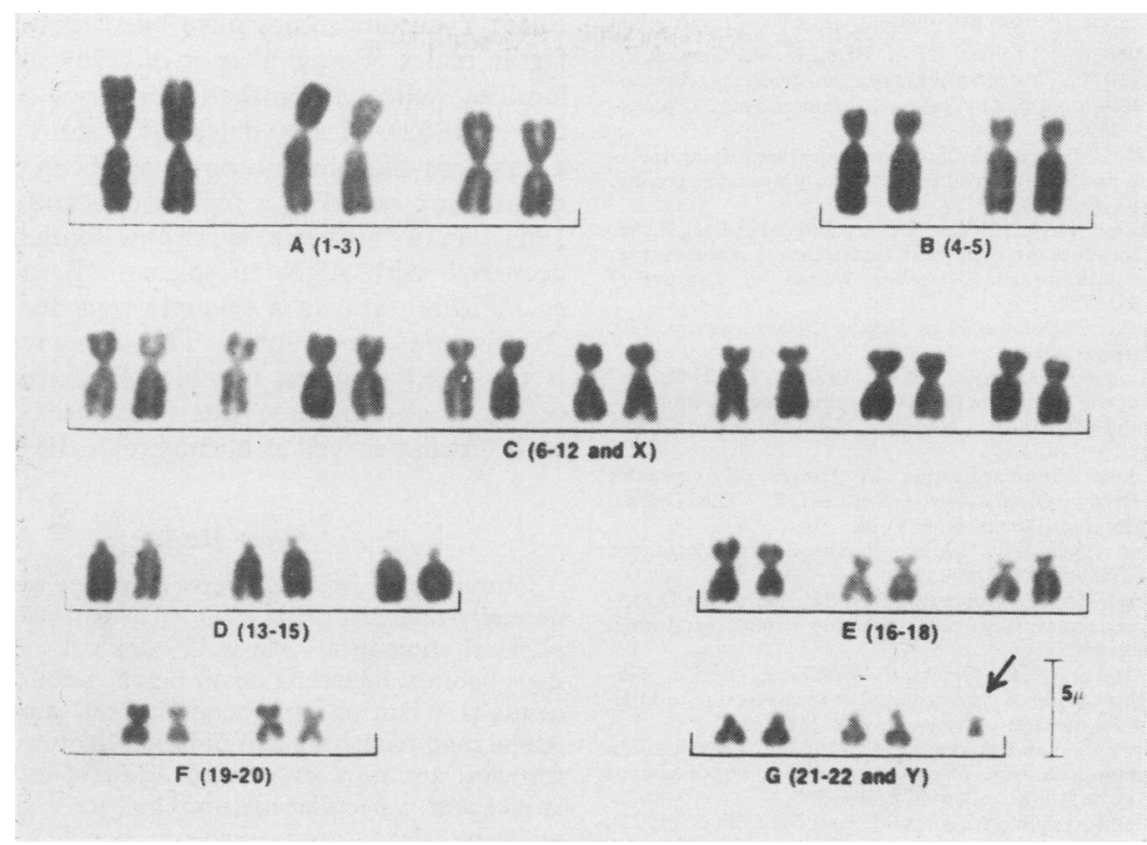

Fig. 1. Karyotype of the patient, showing the deleted Y.

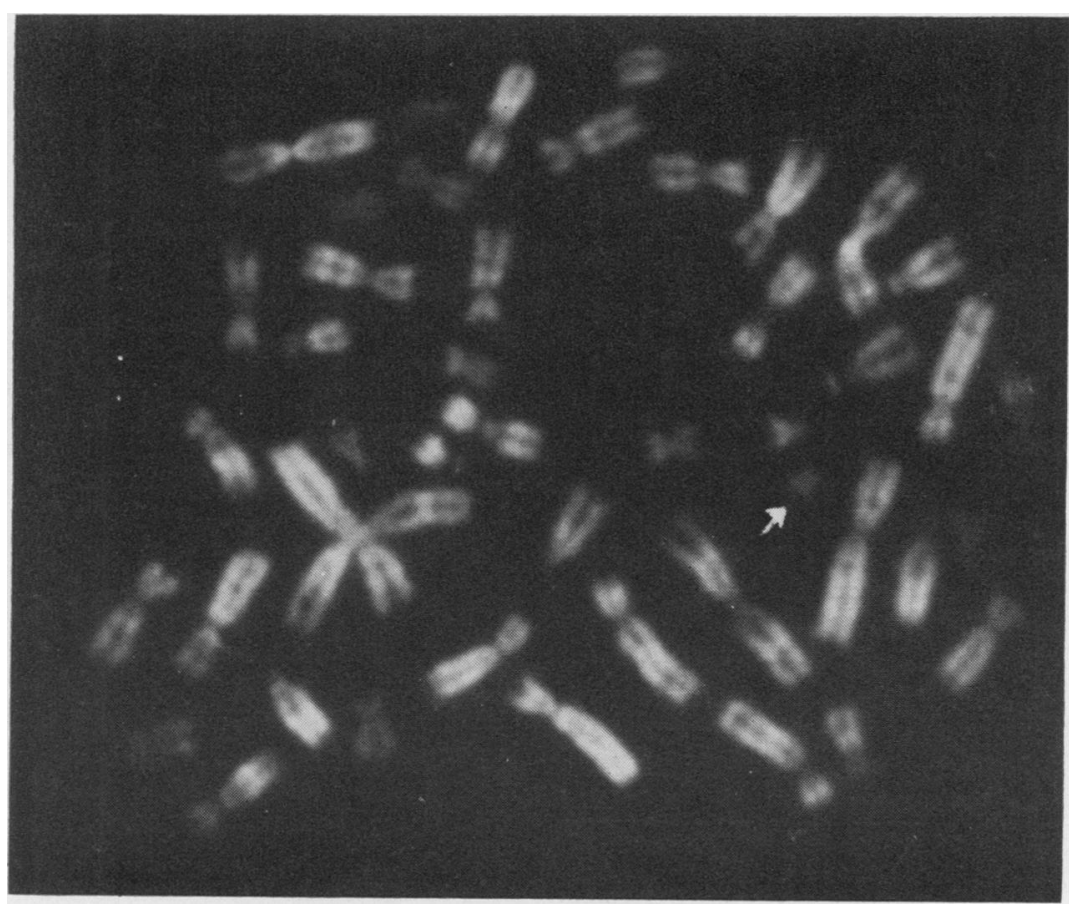

Fig. 2. Patient's fluorescent metaphase cell, stained with quinacrine dihydrochloride $(\times 2000)$. Note the pale, tiny metacentric $Y$. 


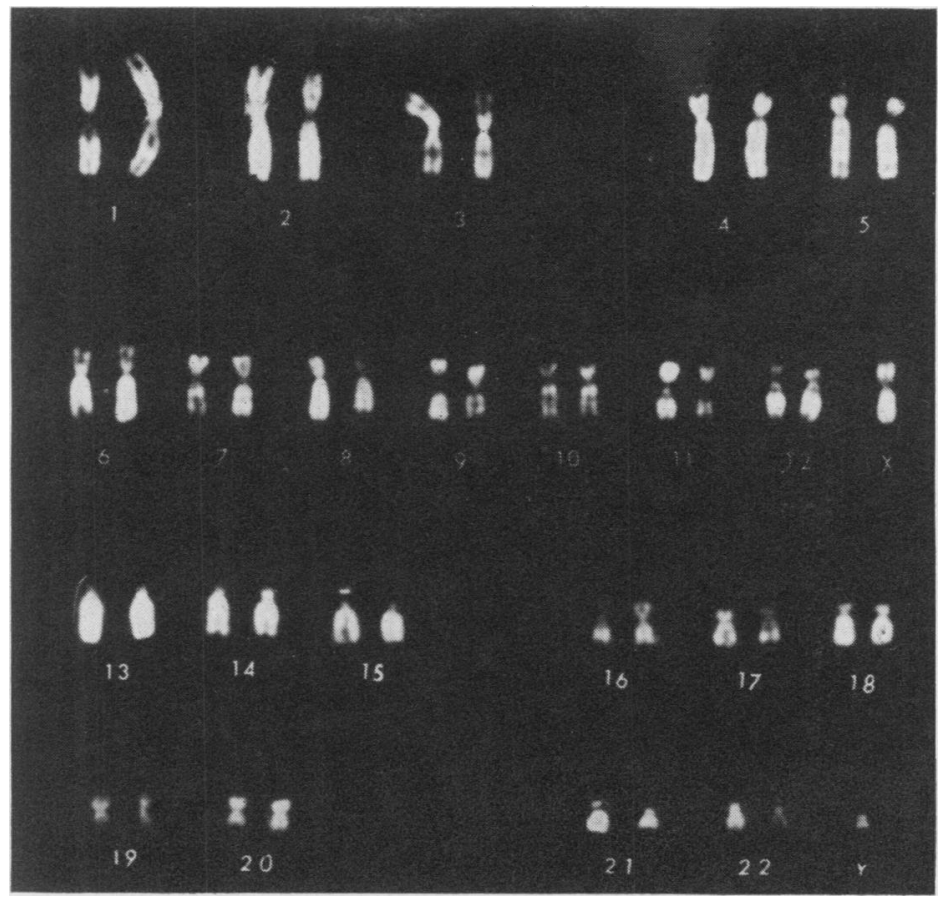

FIG. 3. Karyotype of fluorescent cell shown in Fig. 2.

Because of these unexpected findings, chromosome analysis was done on blood from his phenotypically-normal older brother (height $179 \mathrm{~cm}$ ), and a morphologically similar karyotype, with a tiny non-fluorescing $\mathrm{Y}$, was found. Neither his normal brother nor the patient displayed metaphase plates with unusual fluorescing regions in any of the autosomes that could suggest a translocation of $Y$ long arm material. As is shown in Fig. 4, the aberrant $Y$ is approximately 1 micron in length and very metacentric.

\section{Discussion}

The fact that the patient demonstrates normal male somatic development and is of average height, despite such an extensive long arm $\mathrm{Y}$ deletion, indicates that most of the long arm, including the fluorescent portion of the $\mathrm{Y}$ chromosome, is not necessary for male development. This observation is strengthened because his older brother, with a similar deleted $Y$, is normal and fertile. It would seem reasonable to assume that the missing $Y$ chromosomal material is not the cause of the mental retardation observed in the propositus, and also that a major Y deletion is consistent with normal fertility since the brother and father, who must have had the same deleted $Y$, both had 4 children.
It is not possible to determine whether the abnormal $\mathrm{Y}$ chromosome arose through a simple deletion of the $\mathrm{Y}(\mathrm{Yq}-)$ or whether it is an isochromosome of the short arm (Ypi). Both interpretations are consistent with the observed morphology. If the aberration were an isochromosome of the Y short arm, this would prove that the long arm is devoid of any significant male-determining genes or fertility factors. Furthermore, if the abnormal $\mathrm{Y}$ in the present case were an isochromosome of the short arm, the patient as well as his normal brother and father would have 2 doses of the genetically-significant part of the Y, and would therefore be expected to show features of the XYY syndrome. Although the range of phenotypic variation associated with the XYY karyotype is not sufficiently well-established to make any such determination on physical findings alone, it is of interest to note that the patient does display a number of characteristics that were described in an XYY case by Voorhees et al (1970) eg, acne, a low anterior hairline, gynaecomastia, and shortened 5th finger. $\mathrm{He}$ also manifested the undescended testes so commonly found in childhood XYY cases (Court Brown, 1968). Despite these XYY characteristics which support the possibility that we may be dealing with a $\mathrm{Y}$ short arm isochromosome, it is not possible to discriminate 


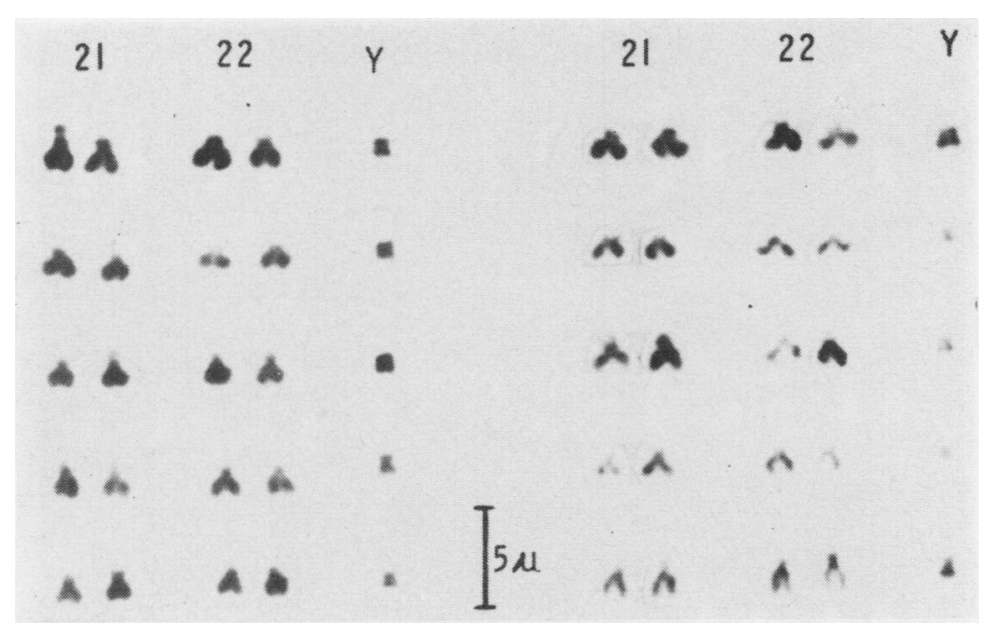

FIG. 4. Partial karyotypes of the G chromosomes with the minute $Y$, taken from the patient (left) and his normal brother (right).

with certainty between a Ypi or Yq- on cytological or clinical grounds. What can be stated unequivocally, however, is that all or most of the long arm of the $\mathrm{Y}$ chromosome appears to be genetically inert.

Other cases in the literature also suggest that the long arm of the $\mathrm{Y}$ chromosome is devoid of active genetic factors. For example, Noel et al (1971) describe a family in which the $\mathrm{Y}$ long arm was translocated onto a $\mathrm{D}$ chromosome, where it showed characteristic $\mathrm{Y}$ fluorescence and resulted in a fluorescent $Y$ body in the interphase nuclei of the females who had it, with 2 such bodies in the interphase nuclei of the male carriers. However, there was no phenotypic effect in the carriers of this translocated Y material; the 3 females who had this translocation in addition to $2 \mathrm{X}$ chromosomes were completely normal, showed no masculinization, and were fertile. Two cases of Turner-like females with presumed isochromosomes of the long arm of the $\mathrm{Y}$ have been described by Jacobs and Ross (1966). Although they were somewhat taller than is found with the $45, \mathrm{X}$ constitution $(155 \mathrm{~cm}$ and $163 \mathrm{~cm}$, respectively), they did have gonadal dysgenesis with no secondary female sex development and no sign of masculinization, except for a deep voice in one of them.

Evidence that male-determining factors are located on the short arm of the $\mathrm{Y}$ chromosome, very close to the centromere, is provided by McIlree et al (1966) who described a dicentric $Y$ chromosome in each of 2 phenotypically-normal males with normal-sized testes. Despite the fact that only the small pericentromeric portion of the $\mathrm{Y}$ short arm was included together with the duplicated long arms in the dicentric, normal male development occurred, although both men showed azospermia (probably due to the meiotic difficulties caused by a dicentric chromosome). This finding is in marked contrast to the immature female differentiation observed with an isochromosome of the $\mathrm{Y}$ long arm, where no short arm material at all was present (Jacobs and Ross, 1966).

An extreme Y deletion, in which only the pericentromeric portions appear to be present, has been reported by Nakagome et al (1965) in a $2 \frac{1}{2}$-year-old boy with severe mental retardation. The deleted $Y$ in their case resembles a tiny dot, yet normal male differentiation occurred, both testes were descended, and the height and body proportions were normal. It is not possible to say whether such an extensive $Y$ deletion would be compatible with fertility, as the affected boy's father had a normal Y chromosome. It is of significance that in at least 2 cases, that of Nakagome et al (1965) and the patient presented here, very little $\mathrm{Y}$ material was adequate to initiate a fetal testis and normal male differentiation. The present case is the only one of which we are aware in which such an extremely deleted $\mathrm{Y}$ is associated with fertility in both the normal brother and father of the propositus.

It thus appears that the developmentally significant portion of the $\mathrm{Y}$ chromosome is very small and non-fluorescent, with fertility and height factors on the short arm or very close to the centromere of the long arm. Since the distal long arm of the $\mathrm{Y}$ appears 
to be devoid of any genes or factors necessary for normal male development, this raises questions as to why it exists in its present form, and whether it may have some other functions. The existence of the fluorescing portion of the $Y$ long arm may be explained as the result of evolutionary change involving the accumulation of non-functional genes on sheltered chromosomes, which Nei (1970) has demonstrated can occur in a reasonable period of evolutionary time. This process may explain the observed polymorphism in Y length, for unlike the $\mathrm{X}$ chromosome, in which deletions or duplications could present problems during meiosis, the $Y$ chromosome has no similar restrictions. Furthermore, since survival is possible without the $\mathrm{Y}$ but not without an $\mathrm{X}$ chromosome, and since both the $\mathrm{X}$ and $\mathrm{Y}$ are believed to have evolved from a homologous pair of autosomal chromosomes, there must have been preferential inactivation of the genes of the $Y$ chromosome. This inactivation would promote differentiation between the sex chromosomes and reduce the possibility of crossing-over. Lack of differentiation between the gonosomes could put a species at a selective disadvantage by making for a high incidence of intersex. That such inactivation occurred is suggested by the fact that there is virtually no recombination between the $X$ and $Y$ in organisms with well-differentiated sex chromosomes (Nei, 1970).

Despite the lack of structural genes, it is possible that the fluorescing $\mathrm{Y}$ long arm does have a function in orienting this chromosome in the sex bivalent during meiosis, when, as has been shown by Pearson and Bobrow (1970), the short arm of the Y enters into a terminal association with the $\mathrm{X}$ chromosome. The fact that fertility was not impaired in the present family may indicate that the $\mathrm{Y}$ aberration is indeed an isochromosome of the short arm, in which case it would not matter which end associated with the $\mathrm{X}$. On the other hand, diminished fertility was noted by Muldal and Ockey (1962) in a family in which nearly one half of the $Y$ long arm was deleted; and dicentric Ys are associated with infertility, with the $\mathrm{X}$ and $\mathrm{Y}$ appearing as univalents in the majority of cells at diakinesis (Mcllree et al, 1966).

\section{Summary}

Normal male somatic development was found in a mentally-retarded man with an extreme deletion of the $\mathrm{Y}$, which had the appearance of a small metacentric chromosome. Since the normal, fertile brother of the patient was shown to have the same $Y$ anomaly, it appears certain that the fluorescing long arm portion of the $\mathrm{Y}$ is not necessary for total male differentiation, including fertility. Although it was not possible to establish whether the $\mathrm{Y}$ anomaly represents a long arm deletion or a short arm isochromosome, this study demonstrates that most or all of the $\mathrm{Y}$ long arm is genetically inert.

LORRAINe F. MEISNER and STANLEY L. INHORN

Cytogenetics Unit, State Laboratory of Hygiene, The University of Wisconsin Medical Center, Madison, Wisconsin, USA

REFERENCES

Borgaonkar, D. S., McKusick, V. A., Herr, H. M., de los Cobos, L., and Yoder, O. C. (1969). Constancy of the length of the human Y chromosome. Annales de Génétique, 12, 262-264.

Court Brown, W. M. (1968). Males with an XYY sex chromosome complement. Fournal of Medical Genetics, 5, 341-359.

Ferguson-Smith, M. A., Boyd, E., Ferguson-Smith, M. E., Pritchard, J. G., Yusuf, A. F. M., and Gray, B. (1969). Isochromosome for long arm of $Y$ chromosome in a patient with Turner's syndrome and sex chromosome mosaicism (45,X/46,XYqi). Fournal of Medical Genetics, 6, 422-425.

Jacobs, P. A. and Ross, A. (1966). Structural abnormalities of the $Y$ chromosome in man. Nature, 210, 352-354.

Lo, M. T. and Kobernick, S. T. (1965). $\mathrm{X}^{\prime \prime} \mathrm{y}^{\prime \prime} / \mathrm{XO}$ mosaicism in a phenotypic intersex. American fournal of Clinical Pathology, 43, 251-255.

McIlree, M. E., Price, W. H., Court Brown, W. M., Tulloch, W. S., Newsam, J. E., and Maclean, N. (1966). Chromosome studies on testicular cells from 50 subfertile men. Lancet, 2, 69-71.

Muldal, S. and Ockey, C. H. (1962). Deletion of Y chromosome in a family with muscular dystrophy and hypospadias. British Medical fournal, 1, 291-294.

Nakagome, Y., Sasaki, M., Matsui, I., Kawazura, M., and Fukuyama, Y. (1965). A mentally retarded boy with a minute $\mathrm{Y}$ chromosome. Fournal of Pediatrics, 67, 1163-1167.

Nei, M. (1970). Accumulation of nonfunctional genes on sheltered chromosomes. American Naturalist, 104, 311-322.

Noel, B., Emerit, I., Luciani, J. M., and Quack, B. (1971). A familial Y/autosome translocation in man. Clinical Genetics, 2, $1-6$.

Pearson, P. L. and Bobrow, M. (1970). Definitive evidence for the short arm of the $\mathrm{Y}$ chromosome associating with the $\mathrm{X}$ chromosome during meiosis in the human male. Nature, 226, 959-961.

Voorhees, J. J., Hayes, E., Wilkins, J., and Harrell, E. R. (1970). The XYY chromosomal complement and nodulocystic acne. Annals of Internal Medicine, 73, 271-276.

\section{A Ring-20 Chromosome}

Except in neoplastic cells, some haematopoietic abnormalities, and in cells known to be damaged by irradiation or chemicals or viruses, chromosomal abnormalities involving the F group (19-20) are rare. This report describes a ring- 20 chromosome in a mentally retarded boy with a behaviour problem, seizures, and microcephaly.

Received 10 April 1972 